\title{
Benefits of Reducing Air Emissions: Replacing Conventional with Electric Passenger Vehicles
}

\author{
Ofira Ayalon ", Bernanda Flicstein, Amos Shtibelman \\ Natural Resource \& Environmental Research Center, University of Haifa, Haifa, Israel. \\ Email: *aofira@gmail.com \\ Received July $1^{\text {st }}, 2013$; revised August $3^{\text {rd }}, 2013$; accepted September $4^{\text {th }}, 2013$ \\ Copyright (C) 2013 Ofira Ayalon et al. This is an open access article distributed under the Creative Commons Attribution License, \\ which permits unrestricted use, distribution, and reproduction in any medium, provided the original work is properly cited.
}

\begin{abstract}
The study estimated the cost of local and global air emissions, and to compare the differences between electric passenger vehicles (EV) and conventional, internal combustion engine (ICE) vehicles. The air emissions were estimated for the year 2020, for Denmark, France and Israel, because of their significantly different fuel mixes to produce electricity - a high percentage of renewable energy, mainly nuclear energy and high fossil fuels, respectively. Air emissions from electricity production and conventional traffic were calculated for each country and then multiplied by the specific country's cost of emissions. Subtracting the total cost of electricity production from the total cost of conventional transportation yields the total benefit for each of the economies studied. The environmental benefit, depending on EV penetration rates, was found to be in the range of 7.8 to $133 \mathrm{MEUR} / \mathrm{year}$ for Denmark, 94 to1948 MEUR/year for France and only 4 to $82 \mathrm{MEUR} /$ year for Israel, whose energy mix is the most polluting. Our analysis also shows higher potential benefits when replacing passenger car fleets comprising a high percentage of diesel cars with EVs, as well as in highly populated areas. In addition, we quantified the differences between EVs with fixed batteries and the new switch able battery concept (EASYBAT), as part of the EU $7^{\text {th }}$ Framework Program me. The additional electricity demands for the EASYBAT concept are negligible, and therefore, do not change the overall conclusion that the cleaner the electricity energy mix and the higher the penetration of EVs, the higher the environmental benefits achieved.
\end{abstract}

Keywords: Air Emissions; Electric Vehicles; Passenger Car Externalities; Power Generation Externalities; Battery-Switch EASYBAT EU FP7

\section{Introduction}

Two major forces are driving the world to find alternative fuels for conventional transportation. The first is the increasing concern about local and global air emissions and their effects on areas such as human health, agricultural crops and property value. The second force is the need to reduce the world's dependency on oil, and will not be discussed in this paper.

Gasoline- and diesel-powered passenger vehicles are major contributors of many noxious emissions, on the local level, including carbon monoxide (CO), nitrogen oxides $\left(\mathrm{NO}_{\mathrm{x}}\right)$ and fine particulate matter $\left(\mathrm{PM}_{2.5}\right)$ [1]. [2,3] showed that, although $\mathrm{PM}_{2.5}$ is directly related to vehicle exhaust emissions, $\mathrm{PM}_{10}$ emissions originate from nonexhaust emissions. Since our analysis is based on tankto-wheel emissions as will be described shortly, we may

"Corresponding author. regard transportation as the sole contributor of $\mathrm{PM}_{2.5}$. Within urban areas, the contribution by passenger cars is particularly high [4]. The effect of traffic on urban air quality in Israel can be most accurately assessed on Yom Kippur (the Day of Atonement - the holiest day in the Jewish calendar), when the streets are practically empty of traffic for the entire day, whereas heavy industry (including power plants and oil refineries) reduces its capacity only slightly [5]. The data show that pollutant concentrations in the large urban centers are reduced nearly to zero.

Growing evidence links vehicle pollutants to severe health effects such as respiratory, cardio-pulmonary diseases and lung cancer [6]. According to the World Health Organization (WHO), car-exhaust emissions are responsible, worldwide, for more deaths than road accidents [1].

Numerous studies have shown that introduction of electric vehicles (EV) can contribute to pollution abatement, mainly $\mathrm{CO}_{2}$, from gasoline- and diesel-powered 
vehicles (e.g., [7-10]). All these studies concluded that introduction of EVs will be beneficial, especially where the power for charging the vehicles will be generated from alternative, low emissions, sources (renewable or nuclear).

The economic benefits of improving air emissions by replacing internal combustion engine (ICE) vehicles with EVs are country-specific, as they not only depend on specific meteorology [11], synoptic patterns $[12,13]$ and geographic variation [14]. They are also a function of population density $[15,16]$ and of the type of vehicles replaced (for example, $\mathrm{NO}_{\mathrm{x}}$ and $\mathrm{CO}_{2}$ emissions from diesel cars are higher than from gasoline cars, therefore, one may expect that replacing diesel cars will be more beneficial than replacing gasoline cars).

These economic benefits should be assessed according to various inputs, such as the specific energy mix required to produce the electricity, the specific cost of air emissions (or benefits gained by improving it) and the population affected by the pollution.

The current study assessed the benefits of introducing EVs in Denmark, France and Israel, as these benefits have not been previously evaluated and these countries are characterized by very different fuel mixes to produce electricity and by different car fleet compositions. In addition, the study enables calculation of the benefits of improved air quality in urban areas.

It is important to note that these countries were the first to introduce the EV developed by Renault, as part of the EASYBATEU FP7 project [17]

\section{Methodology}

The study was conducted in several stages:

1) Energy mix for electricity production and related air emissions. Assessment of anticipated air emissions from the projected electricity production mix (tons pollutant $/ \mathrm{kWh}$ ) for the different countries under study, for the year 2020 .

2) Passenger car stock and related emissions. According to the national assessments of passenger car stock in 2020, we estimated air emissions from ICE vehicles according to Euro 6 standards and real-world emissions, under different scenarios of EV penetration to the market.

3) Electricity needs for charging EV cars. Calculation of the electricity needs for charging EV cars and the share of the additional needs in the overall electricity consumption was analysed for every country.

4) Air emission costs. Calculation of the externalities ${ }^{2}$

${ }^{1}$ Easybat is an FP7 STREP (Specific Targeted Research) project. In the field of transport, the project addresses the topic of smart storage integration. The project mission is to develop models and generic interfaces for easy and safe battery insertion and removal in electric vehicles. resulting from the electricity production needed for charging the EV cars compared to the air emissions from the same number of ICE vehicles.

5) Life cycle differences between the proposed switchable battery (SB) and the conventional FB (fixed battery, e.g., Nissan Leaf). The only difference found was the amount of electricity needed at the battery switch stations for battery temperature control. Therefore, this electricity consumption and the related environmental externalities will be subtracted from the benefits found in the next stage.

6) Quantification of benefits from reducing emissions by replacing conventional cars with EVs. For Denmark and France, the analysis was performed according to the Extern E Methodology developed by the European Commission [16,19]. For the analysis in Israel, we used the environmental quantification produced by $[20,21]$. It is noteworthy that the Israeli figures were obtained using the benefit-transfer approach ${ }^{3}$.

\section{Assumptions}

\subsection{Anticipated Energy Mix for Electricity Production}

The projected fuel mixes for electricity production in Denmark, France and Israel are presented in Table 1, according to national policy papers and energy outlooks [22-24].

As much effort is invested today in reducing the specific emissions resulting from electricity production, it is reasonable to assume that by 2020 , they will be lower than at present. Yet, we calculated primary air pollutants and $\mathrm{CO}_{2}$ emissions from electricity production according to present data. There fore, the use of current limits, regardless of the techniques used to achieve them, is a stringent assumption with respect to the present research. For

Table 1. Projected share of fuel mix for electricity production for 2020.

\begin{tabular}{cccc}
\hline & Denmark & France & Israel \\
\hline \multicolumn{4}{c}{ Fossil energy } \\
\hline Coal and lignite & $27 \%$ & & \\
Gas & $22 \%$ & & $65 \%$ \\
Thermal & & $8.7 \%$ & \\
Oil & $1 \%$ & \\
\hline \multicolumn{4}{c}{ Non-fossil and RE } \\
\hline Wind \& other renewables & $50 \%$ & $4 \%$ \\
Nuclear & & $73.7 \%$ & \\
Hydro & & $13.6 \%$ \\
\hline
\end{tabular}

${ }^{2}$ Externalities are costs or benefits arising from an economic activity that affects someone other than the people engaged in the economic activity and are not reflected fully in prices [18]. Benefits are obtained by decrease in social costs, e.g., by reducing air emissions.

${ }^{3}$ The benefit-transfer approach enables evaluation of externality values found in various studies in specific countries and their adaptation to other countries using econometric methods. 
the purpose of the analyses presented in this study, we shall refer to this mix as BAU (Business As Usual).

Given the BAU energy mix in Table 1 and each country's anticipated emission limits, we calculated the total emissions from $1 \mathrm{kWh}$ of electricity produced. The figures are provided in Table 2.

\subsection{Anticipated Passenger Car Stock and Emissions from ICE Vehicles}

The projected car fleet composition in the countries under study is presented in Table 3, calculated according to [25-27].

[28] sets two emission standards for the registration and sale of new passenger vehicles, vans and commercial vehicles intended for the transport of passengers or goods (Euro 5 standard came into force on January $1^{\text {st }} 2011$ and Euro 6 standard will come into force on the January $1^{\text {st }}$ 2015). Vehicles that do not comply with the limits set in the Euro 5 and 6 standards must be refused registration in the member state [28]. Actions targeting the reduction of $\mathrm{CO}_{2}$ emissions in the transport sector have been discussed since the early 1990s. In 2007, a new objective target for emissions was proposed at a level of $120 \mathrm{~g}$ $\mathrm{CO}_{2} / \mathrm{km}$ by 2012. Later, however, this target was set to a level of $130 \mathrm{~g} / \mathrm{km}$ [29].

This study considers Euro 6 emissions for ICE vehicles which, according to different penetration scenarios, will be replaced by EV.

Nevertheless, several studies have indicated that, in particular, on-road (real-world) $\mathrm{NO}_{\mathrm{x}}$ emissions from lightduty diesel vehicles might substantially exceed the emission levels identified during emissions testing in the laboratory. [30] showed that Portable Emission Measurement Systems indicate that average $\mathrm{NO}_{\mathrm{x}}$ emissions of Euro 5 diesel vehicles are $0.62 \pm 0.19 \mathrm{~g} / \mathrm{km}\left(\mathrm{grams} \mathrm{NO}_{\mathrm{x}}\right.$ per kilometer), which substantially exceed the Euro emission limits.

On-road $\mathrm{NO}_{\mathrm{x}}$ emissions of gasoline vehicles, as well as $\mathrm{CO}$ and THC (total hydrocarbon) emissions of both diesel and gasoline vehicles generally stay within Euro emission limits.

During on-road testing, the average emissions from light-duty diesel and gasoline vehicles are $189 \pm 51 \mathrm{~g}$ $\mathrm{CO}_{2} / \mathrm{km}$ and $162 \pm 29 \mathrm{~g} \mathrm{CO}_{2} / \mathrm{km}$, respectively, thereby exceeding the $\mathrm{CO}_{2}$ emissions as specified during laboratory testing by $21 \% \pm 9 \%$. The magnitude of on-road emissions varies depending on vehicle type, operation mode, route characteristics and ambient conditions; the higher the emission from ICE vehicles, the greater the benefits from replacing these vehicles. To conduct a conservative analysis in this study, we used the following real-world emissions: $\mathrm{NO}_{\mathrm{x}}$ emissions from diesel cars$0.6 \mathrm{~g} / \mathrm{km}$ instead of $0.08 \mathrm{~g} / \mathrm{km} \mathrm{[28]} \mathrm{and} \mathrm{CO}_{2}$ emissions$160 \mathrm{~g} / \mathrm{km}$ instead of $130 \mathrm{~g} / \mathrm{km}$ for both gasoline- and diesel-powered vehicles [28]. In all other parameters and with respect to gasoline cars, we used the Euro 6 standards.

Table 4 presents the emission limits of Euro 6 and real-world emissions used in this study.

Table 2. Calculated air emissions from $1 \mathrm{kWh}$ electricity production for year 2020.

\begin{tabular}{|c|c|c|c|}
\hline Average Emissions (g/1kWh) & Denmark & France & Israel \\
\hline $\mathrm{CO}_{2}$ & 149.9 & 33.2 & 498 \\
\hline $\mathrm{SO}_{2}$ & 0.05 & 0.08 & 0.18 \\
\hline $\mathrm{NO}_{\mathrm{x}}$ & 0.25 & 0.07 & 0.35 \\
\hline NMVOC & 0.003 & 0.009 & 0.01 \\
\hline $\mathrm{PM}_{10}$ & 0.003 & 0.005 & 0.03 \\
\hline As & $1.46 \mathrm{E}-06$ & $9.4 \mathrm{E}-07$ & \\
\hline $\mathrm{Cd}$ & $2.8 \mathrm{E}-07$ & $1.4 \mathrm{E}-07$ & Total Heavy metals (excluding Hg) \\
\hline $\mathrm{Cr}$ & $1.96 \mathrm{E}-06$ & $2.1 \mathrm{E}-06$ & \\
\hline $\mathrm{Ni}$ & $1.5 \mathrm{E}-05$ & $1.2 \mathrm{E}-05$ & $7.50 \mathrm{E}-05$ \\
\hline $\mathrm{Pb}$ & $4.4 \mathrm{E}-06$ & $2.3 \mathrm{E}-06$ & \\
\hline $\mathrm{Hg}$ & $1.6 \mathrm{E}-06$ & $1.9 \mathrm{E}-07$ & $1.5 \mathrm{E}-06$ \\
\hline Dioxin & $1.2 \mathrm{E}-11$ & $1.4 \mathrm{E}-12$ & $1.21 \mathrm{E}-12$ \\
\hline
\end{tabular}

Table 3. Projected passenger cars (in millions) and average kilometers traveled for year $2020^{*}$.

\begin{tabular}{|c|c|c|c|}
\hline & Denmark & France & Israel \\
\hline Gasoline & $1.72(79.3 \%)$ & $15.5(45.1 \%)$ & $2.6(96.3 \%)$ \\
\hline Diesel & $0.45(20.7 \%)$ & $18.9(54.9 \%)$ & $0.1(3.7 \%)$ \\
\hline Total & 2.17 & 34.4 & 2.7 \\
\hline Annual Average Kilometers Travelled (Km) & 19,000 & 12,800 & 16,800 \\
\hline Annual Average Kilometers Travelled (Km) diesel & NA & 16,000 & NA \\
\hline Annual Average Kilometers Travelled(Km) gasoline & NA & 9,000 & NA \\
\hline Annual Average Kilometers Travelled & $\begin{array}{c}\text { Urban }(35 \%) \text {, Rural }(46 \%), \\
\text { Highways }(19 \%)\end{array}$ & $\begin{array}{c}\text { Urban }(27.9 \%) \\
\text { Rural }(44.5 \%) \text {, Highways }(27.6 \%)\end{array}$ & $\begin{array}{c}\text { Urban }(84.3 \%) \\
\text { Non-Urban }(15.7 \%)\end{array}$ \\
\hline
\end{tabular}

${ }^{*}$ We assume that future figures will not change significantly from current national figures. 
Table 4. Emission limits of Euro 6 and real-world emissions (gr/km).

\begin{tabular}{|c|c|c|c|c|c|c|}
\hline & CO & THC & $\mathbf{T H C}+\mathrm{NO}_{\mathrm{x}}$ & $\mathbf{N O}_{\mathbf{x}}$ & $\mathbf{P M}$ & $\mathrm{CO}_{2}$ \\
\hline \multicolumn{7}{|c|}{ Diesel } \\
\hline Euro 6 & \multirow{2}{*}{0.50} & - & \multirow{2}{*}{0.17} & 0.08 & \multirow{2}{*}{0.005} & 130 \\
\hline Real world & & - & & 0.60 & & 160 \\
\hline \multicolumn{7}{|c|}{ Gasoline } \\
\hline Euro 6 & \multirow{2}{*}{1.0} & \multirow{2}{*}{0.10} & - & \multirow{2}{*}{0.06} & \multirow{2}{*}{0.005} & 130 \\
\hline Real world & & & - & & & 160 \\
\hline
\end{tabular}

\subsection{Electricity Needs for Charging EV Cars}

According to different EV penetration rates (3\%, 20\%, $40 \%$ ), it was found that in Denmark, the electricity demand will grow by $0.65 \%, 4.34 \%$ and $8.68 \%$, respectively. For the same respective rates in France, we anticipate an increase of $0.53 \%, 3.55 \%$ and $7.11 \%$, and in Israel, of $0.42 \%, 2.8 \%$ and $5.59 \%$.These electricity demands include the negligible needs of the EASYBAT concept that will be introduced in Section 3.5.

We assume that no increase in electricity production will be necessary, as existing power plants will be used.

\subsection{Air Emission Costs}

Air pollution costs are caused by the emission of air pollutants such as particulate matter (PM), $\mathrm{NO}_{\mathrm{x}}, \mathrm{SO}_{2}$ and VOC (volatile organic compounds). They include health costs, building and material damages and crop losses, as well as costs of further damage to the ecosystem (biosphere, soil, water). Health costs (mainly caused by PM from exhaust emissions or from transformation of other pollutants) are by far the most important cost category (e.g., [31]). The state of research on these costs is far more advanced than for the other components, mainly based on estimations carried out by the Extern E model, funded by several EU-research projects $([16,19])$.

In this study, we addressed tank-to-wheel air emissions; that is to say, we refer only to primary air emissions associated with the vehicle's actual operation (and not secondary pollutants such as Ozone).

Externalities for Denmark and France were calculated according to data provided by $[16,19]$. The data provided by $[20,21]$ were used to calculate the relevant assessments for Israel.

Table 5 presents the different costs (in 2000 EUR) of air pollutants from transportation and electricity production in the countries under study.

Using the Extern E data, the external costs of all air pollutants in France were found to be significantly higher than in Denmark. The possible explanation for this includes different meteorological conditions and different population densities residing in urban areas. The urban population in Denmark is $24.5 \%$ [32], whereas in France,
$34 \%$ of the population resides in cities with more than 500,000 inhabitants [33]. The denser the population in the cities, the higher the environmental costs associated with air pollution generated in the cities.

The Israeli studies assessing the air pollution costs were based on the Extern E project, but, as discussed above, several amendments and benefit-transfer techniques were used to fit the Israeli economy, meteorological conditions and the fact that Israel is a densely populated country (according to [34], 6,808,000 out of 7,419,000 inhabitants live in metropolitan areas with an average of 361 inhabitants per $\mathrm{km}^{2}$ ). Hence, no distinction is made in Israel between urban and rural areas.

One may argue about the accuracy of the official Israeli figures provided by [20,21], but we use them in this study because, to the best of our knowledge, no better data prevail.

Although the aforementioned pollutants impose different costs on the countries under study, the same damage costs of $\mathrm{CO}_{2}$, heavy metals and dioxins were used in each country, as shown in Table 6, (following [16,19]).

It is noteworthy that the transportation sector in Europe was responsible for $20.2 \%$ of total greenhouse gas emissions in 2009 [35]. The price that we assumed for $\mathrm{CO}_{2}$ in our analysis (40 EUR/ton) is relatively conservative, as according to the United States Environmental Protection Agency [36], the price could be higher than $50 \mathrm{EUR} / \mathrm{ton}$.

Table 5. Air emission costs in 2000 EUR/ton of substance emitted.

\begin{tabular}{ccccc}
\hline \multirow{2}{*}{ Substance } & \multicolumn{4}{c}{ Costs of Air Emissions (2000 EUR/ton) } \\
\cline { 2 - 5 } & & Denmark & France & Israel \\
\hline \multirow{2}{*}{$\mathrm{NO}_{\mathrm{X}}$} & Road Transport & 4400 & 7700 & 14,147 \\
& Electricity production & 4400 & 7700 & 3853 \\
\multirow{2}{*}{$\mathrm{NMVOC}$} & Road Transport & 700 & 1400 & 4022 \\
& Electricity production & 700 & 1400 & 513 \\
$\mathrm{SO}_{2}$ & Road Transport & 5200 & 8000 & 8367 \\
& Electricity production & 5200 & 8000 & 6653 \\
$\mathrm{PM}_{2.5}$ & Road Transport & 185,768 & 216,706 & 27,328 \\
$\mathrm{PM}_{10}$ & Electricity production & 5475 & 11,486 & 9496 \\
$\mathrm{CO}$ & Road Transport & 500 & 500 & 1224 \\
\hline
\end{tabular}

Table 6. Air emission costs in 2000 EUR/ton of substance emitted.

\begin{tabular}{cc}
\hline Substance & Costs of pollutant (2000 Euro/ton) \\
\hline $\mathrm{CO}_{2}$ & 40 \\
Arsenic (As) & 80,000 \\
Cadmium $(\mathrm{Cd})$ & 39,000 \\
Chrome $(\mathrm{Cr})$ & 31,500 \\
Nickel $(\mathrm{Ni})$ & 4000 \\
Lead $(\mathrm{Pb})$ & 600,000 \\
Mercury $(\mathrm{Hg})$ & $8,000,000$ \\
Dioxin & $37,000,000$ \\
\hline
\end{tabular}


In this study, we did not present any other benefits of replacing ICE vehicles with $\mathrm{EV}$, such as noise reduction, water and soil pollution reduction, etc.

\subsection{Specific Electricity Demands for the EASYBAT Concept}

To assess the environmental benefits of the EASYBAT concept, we compared the proposed SB with the conventional FB. According to current literature, the driving range of these cars is the same, $160 \mathrm{~km}$ [37], and the life span and the degradation of the battery are also considered equal-160,000 km over 10 years (EASYBAT, personal communication). The SB and FB in their second life and end of life are treated the same, and therefore, no differences exist.

Our basic assumption is that the energy consumption of any EV is $0.2 \mathrm{kWh} / \mathrm{km}$ [38]. In addition, the weight of the SB infrastructure and the electricity consumption of the additional cars is negligible (EASYBAT personal communication).

Nonetheless, to facilitate the SB concept, it is necessary to construct battery switch stations (BSS). The battery's life span is significantly influenced by the charging and storage temperature, therefore, it is crucial to cool (or heat)the battery at the BSS. On arrival, the battery should be connected to a cooling/heating system to achieve the temperature of $20^{\circ} \mathrm{C} \pm 2^{\circ} \mathrm{C}$ (EASYBAT personal communication). In addition, the EASYBAT inventory model assumes a requirement for an extra battery inventory of $2 \%$ for the car fleet in each country where the concept is applied (TUM model, EASYBAT personal communication). These batteries need to be kept at a controlled temperature also when stored at the BSS. According to our analysis, each battery required $1.5 \mathrm{kWh}$ to maintain the required temperature. Therefore, the total electricity demand for the temperature regulation was calculated as $58 \mathrm{GWh}$ (per 1000 batteries in $100 \mathrm{BSS}$, needed for 50,000 vehicles and $160,000 \mathrm{~km}$ travelled for 10 years). Given this electricity consumption, we applied the same methodology as described in Section 3.4.

\section{Results and Discussion}

\subsection{Projected Emissions and Costs from Electricity Production}

Given the total emissions from $1 \mathrm{kWh}$ of electricity produced (Table 2), it can be seen that, due to the fact that the French fuel mix for producing electricity includes 91.3\% of alternative energy (nuclear and renewable energy), France has the lowest emission of each specific pollutant per $\mathrm{kWh}$. Denmark is next, as its fuel mix includes an anticipated $50 \%$ of renewable energy. Israel has the highest percentage of fossil fuel energy, and shows the highest levels of pollution per $\mathrm{kWh}$. By multiplying the cost of air pollutants presented in Tables $\mathbf{5}$ and $\mathbf{6}$ with the emissions from electricity production, we can calculate the emissions external costs per $\mathrm{kWh}$ produced.

The cost of producing $1 \mathrm{kWh}$ in Denmark is 0.00506 EUR, in France the cost is 0.003 EUR and in Israel it is 0.0331 EUR.

\subsection{Benefits of Replacing ICE Vehicles with EV}

Our study included various penetration rates $(3 \%, 20 \%$ and $40 \%$ ) of EVs, whose batteries were charged with the projected energy mix given in Table 1. The emissions from ICE vehicles were evaluated for Euro 6 and realworld emissions, as discussed in Section 3.2 above.

It should be noted that the original EASYBAT FP7 project estimated a larger scope of scenarios, but we present the most likely electricity production estimates. The results are shown in Table 7. The replacement of conventional cars with EVs was calculated for each country according to the specific distribution between diesel and gasoline vehicles.

It can be seen that the higher the EV penetration rate, the larger the reduction in the social cost of emissions. Since real-world ICE vehicle emissions are higher than Euro 6 limits, the benefits of replacing them with EVs will yield even higher benefits.

Since France has the least polluting fuel mix for producing electricity, the option of replacing ICE vehicles in France will yield the highest benefits. We conclude, therefore, that the cleaner the electric energy production used for charging the EVs, the higher the environmental benefits that are achieved.

Most of the environmental benefits, (approximately 70\%) are due to the reduction of $\mathrm{CO}_{2}$ emissions, with a common global price of $40 \mathrm{EUR} / \mathrm{ton}$. As for the other pollutants, the higher the external costs, the higher the environmental benefits of EV in comparison to the ICE vehicles.

In addition, France has the largest share of diesel ICE vehicles (54.9\%). Therefore, their replacement with EV will further increase environmental benefits due to their higher externalities as compared to gasoline vehicles.

\subsection{The Net Benefits of Replacing ICE Vehicles with EVs}

The benefit per car and per 10,000 km driven is subject to the available electricity source. The comparison is made by replacing ICE vehicles emitting pollutants according to Euro 6 standards or real-world measurements.

To calculate the net benefits of the replacement, we calculated the electricity demand to control the temperature of the SB concept. The external costs of this consumed electricity $(58 \mathrm{GWh})$ were subtracted from the external benefits found for the Euro 6 or real-world ICE 
vehicle replaced by EV. The net benefits are presented in Table 8.

It can be seen that in all real-world cases, the replacement of ICE vehicles yields higher benefits compared to the expected Euro 6 emissions. The highest net benefits are obtained for France, since its electricity production is the cleanest and its transportation fleet is comprised of a relatively high number of diesel cars, which are more polluting and therefore, impose higher externalities as compared to gasoline vehicles.

As electricity production in Israel is based on a relatively high percentage of polluting coal, the benefits from the replacement of ICE vehicles with EV will be $50 \%$ of those achieved in Denmark and 60\% than those in France.

\subsection{Prediction of Benefits of Reduced Air Emissions by Replacing ICE Vehicles with EVs}

Our analysis enabled prediction of the anticipated benefits, given the specific conditions of each country facing the introduction of EVs. As already demonstrated, the higher the pollution related to electricity production, the lower are the benefits of replacing ICE vehicles with EVs. On the other hand, if energy used for charging EVs is obtained by renewable, non-polluting resources, the cleaner the electricity production, the greater will be the benefits from the replacement.

In 2020 , the share of energy mix for electricity production used in our study in Demark, France and Israel will consist of $30 \%, 91.3 \%$ and $10 \%$ of alternative energy, respectively. If all electricity is produced by alternative resources (either renewable or nuclear), the benefits for real-world car fleet emissions will increase by $19.7 \%, 5.4 \%$ and $254 \%$ for Demark, France and Israel, respectively.

Another factor influencing the change in benefits depends on car fleet composition.

The higher the percentage of diesel cars replaced, the

Table 7. Annual benefits (MEUR) from ICE replacement with EV at different penetration rates.

\begin{tabular}{|c|c|c|c|c|c|}
\hline Scenario & Country & $\begin{array}{c}\text { Share of EV } \\
\text { (\% of Total presented in Table 3) }\end{array}$ & Share of Renewable Energy (\%) & $\begin{array}{l}\text { ICE emissions } \\
\text { Euro } 6 \text { or Real World }\end{array}$ & Annual benefit (MEUR/year) \\
\hline 1 & \multirow{6}{*}{ Denmark } & \multirow{2}{*}{3} & \multirow{6}{*}{50} & Euro 6 & 7.8 \\
\hline 2 & & & & RW & 10.0 \\
\hline 3 & & \multirow{2}{*}{20} & & Euro 6 & 52.0 \\
\hline 4 & & & & RW & 66.8 \\
\hline 5 & & \multirow{2}{*}{40} & & Euro 6 & 103.9 \\
\hline 6 & & & & RW & 133.6 \\
\hline 7 & \multirow{6}{*}{ France } & \multirow{2}{*}{3} & \multirow{6}{*}{91.3} & Euro 6 & 94.2 \\
\hline 8 & & & & RW & 146.1 \\
\hline 9 & & \multirow{2}{*}{20} & & Euro 6 & 628.1 \\
\hline 10 & & & & RW & 974.3 \\
\hline 11 & & \multirow{2}{*}{40} & & Euro 6 & 1256.2 \\
\hline 12 & & & & RW & 1948.5 \\
\hline 13 & \multirow{6}{*}{ Israel } & \multirow{2}{*}{3} & \multirow{6}{*}{10} & Euro 6 & 4.1 \\
\hline 14 & & & & RW & 6.2 \\
\hline 15 & & 20 & & Euro 6 & 27.2 \\
\hline 16 & & 20 & & RW & 41.2 \\
\hline 17 & & \multirow{2}{*}{40} & & Euro 6 & 54.4 \\
\hline 18 & & & & $\mathrm{RW}$ & 82.4 \\
\hline
\end{tabular}

Table 8. Net benefits (EUR/vehicle*10,000 km) achieved by replacing ICE transportation with EV.

\begin{tabular}{|c|c|c|c|c|c|}
\hline Country & $\begin{array}{l}\text { ICE emissions } \\
\text { Euro 6/Real World }\end{array}$ & Scenario & $\begin{array}{c}\text { External Benefits } \\
(\text { EUR/vehicle*10,000 km) }\end{array}$ & $\begin{array}{l}\text { External costs of SB maintenance } \\
(\text { EUR/vehicle*10,000 km) }\end{array}$ & $\begin{array}{c}\text { Net Benefits } \\
(\text { EUR/vehicle* } 10,000 \mathrm{~km})\end{array}$ \\
\hline \multirow{2}{*}{ Denmark } & Euro 6 & $1,3,5$ & 63 & 0.36 & 62.64 \\
\hline & RW & $2,4,6$ & 81 & 0.36 & 80.64 \\
\hline \multirow{2}{*}{ France } & Euro 6 & $7,9,11$ & 71 & 0.21 & 70.79 \\
\hline & RW & $8,10,12$ & 111 & 0.21 & 110.79 \\
\hline Israel & RW & $14,16,18$ & 46 & 1.66 & 44.34 \\
\hline
\end{tabular}


higher the benefits. The anticipated car fleet in 2020 will be based on $20.7 \%, 54.9 \%$ and $3.7 \%$ of diesel cars in Demark, France and Israel, respectively. If EVs replace only diesel cars (and not according to the specific distribution between diesel and gasoline vehicles as presented in Table 3), in the case of real-world emissions and BAU energy mix, the benefits per car replaced in Denmark, France and Israel will increase by $37 \%, 55 \%$ and $291 \%$, respectively, as compared with replacing only gasoline cars with EVs. This is a very important policy input. If policy makers wish to promote replacement of conventional vehicles with EVs and to maximize the benefits from this replacement, the policy should be oriented toward replacing the diesel vehicles rather than the gasoline cars.

Densely populated urban areas are likely to benefit from improved air quality, due to the change in car fleet from ICE to electric vehicles. BAU conditions in Denmark and France represent $23.3 \%$ and $34 \%$ of the population living in urban areas, respectively. If the entire population in these countries will live in urban areas, the benefits of replacing ICE vehicles in the car fleet with electric vehicles, in "real life" conditions and using a BAU energy mix for producing electricity, the benefit for Denmark and France will increase by $16.4 \%$ and $15.2 \%$, respectively. As mentioned earlier, this calculation is not relevant for Israel, where no distinction is made in the evaluation between urban and rural areas due to the density of the country.

\section{Conclusions}

The aim of this study was to estimate the differences between electric vehicles (EV) and internal combustion engine (ICE) vehicles in terms of air emissions and to analyze and estimate the differences between the EV with fixed battery and the new switch able battery concept (EASYBAT), as part of the FP7 project.

The environmental impact was estimated for three countries-Denmark, France and Israel-for different scenarios of charging mix to produce electricity and different ratios of EV to ICE vehicles. The annual environmental benefits found were in the range of 7.8 to 133 MEUR for Denmark, 94 to 1948 MEUR for France and 4.1 to 82 MEUR for Israel, given that Israel has the most polluting fuel mix for producing electricity.

By taking into account the electricity demand for temperature control of the switch able battery concept, the net annual benefits obtained for Denmark were 63 EUR/ vehicle*10,000 $\mathrm{km}$ and $28 \%$ higher if the real-world scenario was considered. The benefits found for France were $71 \mathrm{EUR} /$ vehicle*10,000 $\mathrm{km}$ and $56 \%$ higher when real-world was estimated, due to the high percentage of diesel cars in the French fleet. Israel would gain the least benefit from the replacement of ICE vehicles with EV,

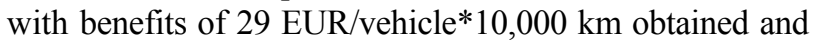

$48 \%$ higher when real-world was evaluated.

It is agreed that practically all countries are facing high social costs associated with transportation. Policies and budgets are allocated to reduce dependency on private transportation; this notwithstanding, all the figures show that the kilometrage driven in private cars is constantly on the increase.

Given that the main source of pollution in dense cities and more than $20 \%$ of greenhouse gas emissions are attributed to transportation, vehicle manufacturers and policy makers should adopt strategies that will promote clean, environmentally-friendly technologies to reduce these costly influences.

In addition, the production of electricity in power plants is a point source of pollution that is continuously monitored and regulated. The foreseen improvements in electricity production, the anticipated efficiency increase and the growing share of renewable energy will further contribute to the environmental benefits described in the present study. These advances will be achieved without the need to replace the electric car fleet.

Our study showed that replacing ICE vehicles with EVs is a significant step for a greater nexus between the social goals and the automotive industry's objectives.

\section{Acknowledgements}

This work was supported by the European Union through the STREP, EASYBAT project. We express special thanks to our colleagues in Better Place, Renault, RWTH Aachen University, DNV KEMA Nederland, Fraunhofer IPA, Danish Technological Institute, TUM-Technische Universitaet Muenchen, TUV Rheinland Kraftfahrt GmbH, Continental Engineering Services \& Products $\mathrm{GmbH}$ and Ernst \& Young.

\section{REFERENCES}

[1] M. Krzyzanowski, B. Kuna-Dibbert and J. Schneider. "Health Effects of Transport Related Air Pollution," World Health Organization, 2005.

http://www.euro.who.int/_data/assets/pdf_file/0006/747 15/E86650.pdf

[2] M. Ketzel, G. Omsted, C. Johansson, I. Düring, L. Gidhagen, A. Lohmeyer, R. Berkowicz and P. Wåhlin, "Estimation and Validation of PM2. 5/PM10 Exhaust and Non Exhaust Emission Factors for Street Pollution Modelling," 2005.

http://www2.dmu.dk/AtmosphericEnvironment/NORPA C/Downloads/Ketzel_etal_UAQ5_short_paper.pdf

[3] EPA, “About PM2.5, PM 10,” 2011. http://www.epa.gov/pmdesignations/faq.htm\#1

[4] M. M. Finkelstein, M. Jerrett and M. R. Sears, "Traffic Air Pollution and Mortality Rate Advancement Periods," American Journal of Epidemiology, Vol. 160, No. 2, 2004, pp. 173-177. http://dx.doi.org/10.1093/aje/kwh181 
[5] MoEP (Israel), "Very Good Air Quality in the Tel Aviv Metropolitan Area and in Jerusalem on Yom Kippur," 2006.

http://www.environment.gov.il/bin/en.jsp?enPage=e Bla nkPage\&enDisplay $=$ view\&enDispWhat $=$ Object\&enDisp Who $=$ News ${ }^{\wedge} 13175 \&$ enZone $=$ e news

[6] International Agency for Research on Cancer (IARC), "Diesel Engine Exhaust Carcinogenic," 2012. http://press.iarc.fr/pr213_E.pdf

[7] C. Thiel, A. Perujo and A. Mercier, "Cost and $\mathrm{CO}_{2}$ Aspects of Future Vehicle Options in Europe under New Energy Policy Scenarios," Energy Policy, Vol. 38, No. 11, 2010, pp. 7142-7151.

http://dx.doi.org/10.1016/j.enpol.2010.07.034

[8] O. Van Vliet, A. S. Brouwer, T. Kuramochi, M. Van Den Broek and A. Faaij, "Energy Use, Cost and $\mathrm{CO}_{2}$ Emissions of Electric Cars," Journal of Power Sources, Vol. 196, No. 4, 2011, pp. 2298-2310.

http://dx.doi.org/10.1016/j.jpowsour.2010.09.119

[9] T. Oxley, A. Elshkaki, L. Kwiatkowski, A. Castillo, T. Scarbrough and H. Apsimon, "Pollution Abatement from Road Transport: Cross-Sectoral Implications, Climate CoBenefits and Behavioural Change," Environmental Science \& Policy, Vol. 19-20, 2012, pp. 16-32. http://dx.doi.org/10.1016/j.envsci.2012.01.004

[10] B. van Wee, K. Maat and C. De Bont, "Improving Sustainability in Urban Areas: Discussing the Potential for Transforming Conventional Car-Based Travel into Electric Mobility," European Planning Studies, Vol. 20, No. 1, 2012, pp. 95-110. http://dx.doi.org/10.1080/09654313.2011.638497

[11] A. Mues, A. Manders, M. Schaap, A. Kerschbaumer, R. Stern and P. Builtjes, "Impact of the Extreme Meteorological Conditions during the Summer 2003 in Europe on Particulate Matter Concentrations," Atmospheric Environment, Vol. 55, 2012, pp. 377-391.

http://dx.doi.org/10.1016/j.atmosenv.2012.03.002

[12] E. Ganor, I. Osetinsky, A. Stupp and P. Alpert, "Increasing Trend of African Dust, over 49 Years, in the Eastern Mediterranean," Journal of Geophysical Research Atmospheres, Vol. 115, No. D7, 2010, Article ID: D012500. http://dx.doi.org/10.1029/2009JD012500

[13] Yuval, D. M. Broday and P. Alpert, "Exploring the Applicability of Future Air Quality Predictions Based on Synoptic System Forecasts," Environmental Pollution, Vol. 166, 2012, pp. 65-74 http://dx.doi.org/10.1016/j.envpol.2012.03.010

[14] R. Beelen, G. Hoek, E. Pebesma, D. Vienneau, K. de Hoogh and D. J. Briggs, "Mapping of Background Air Pollution at a Fine Spatial Scale across the European Union," Science of the Total Environment, Vol. 407, No. 6, 2009, pp. 1852-1867.

http://dx.doi.org/10.1016/j.scitotenv.2008.11.048

[15] Cleaner Air for Europe (CAFE), 2005. http://ec.europa.eu/environment/archives/cafe/pdf/ia_repo rt en050921_summary.pdf

[16] M. C. Maibach, D. Schreyer, H. P. Sutter, B. H. van Essen, R. Boon, Smokers, et al., "Handbook on the Estimation of External Costs in the Transport Sector. Report
Produced within the Study Internalisation Measures and Policies for All external Cost of Transport (IMPACT)," Version 1.1, Commissioned by the European Commission DG TREN Delft, 2008.

http://ec.europa.eu/transport/themes/sustainable/doc/2008 _costs_handbook.pdf

[17] EASYBAT Webpage, 2010. http://www.easybat-project.eu/

[18] Economist, "Economics A-Z Terms," 2013. http://www.economist.com/economics-a-to-z/e\#node-215 29743

[19] P. Bickel and F. Rainer, "Externalities of Energy. Methodology 2005 Update," Institut fur Energiewirtschaft un Rationelle Energieanwendung-IER, Universitat Stuttgart, 2005. http://ec.europa.eu/research/energy/pdf/kina_en.pdf

[20] N. Becker, G. Rosenthal and D. Gabai, "Calculating the External Costs of Air Pollution from Transportation, Industry and Electricity Production (in Hebrew)," 2011. http://www.sviva.gov.il/subjectsEnv/SvivaAir/Documents /airexternalcost/AirNirB_1.pdf

[21] MoEP (Israel), "Balance of Costs and Benefits from Renewable Energy Development in Israel (in Hebrew)," 2011.

http://old.sviva.gov.il/Enviroment/Static/Binaries/Modul Kvatzim/energy_renew-2011_1.pdf

[22] Danish Energy Outlook, 2011. http://www.ens.dk/Documents/Netboghandel\%20-\%20pu blikationer/2011/Danish_Energy_Outlook_2011.pdf

[23] IEA, "Energy Policies of IEA Countries-France," 2009. http://www.iea.org/publications/freepublications/publicati on/france2009.pdf

[24] Y. Rondestein, "Master Plan Electricity Sector 20072030 (in Hebrew)," 2007.

[25] H. Herynkova, "Impact Analysis of Diffusion of Electric Vehicles in Denmark," 2009.

http://lup.lub.lu.se/luur/download?func=downloadFile\&re cordOId $=1474757 \&$ fileOId $=1646989$

[26] L. Coret and S. Fenet, "Mure II Project. Transport Rue Scenarios Evaluation with Mure. French Case Study," 2000. http://www.mure2.com/doc/Tr_f.pdf

[27] Heifetz \& Co. and DHV MED, "Greenhouse Gas Emissions in Israel, a Review of Current Conditions and Examination of Mitigation Measures (in Hebrew)," 2009. http://www.sviva.gov.il/InfoServices/ReservoirInfo/DocL ib2/Publications/P0501-P0600/P0519.pdf

[28] REGULATION (EC) No 715/2007, “On Type Approval of Motor Vehicles with Respect to Emissions from Light Passenger and Commercial Vehicles (Euro 5 and Euro 6) and on Access to Vehicle Repair and Maintenance Information," 2007.

http://eur-lex.europa.eu/LexUriServ/LexUriServ.do?uri= OJ:L:2007:171:0001:0016:EN:PDF

[29] REGUlATION (EC) No 443/2009, “Setting Emission Performance Standards for New Passenger Cars as Part of the Community's Integrated Approach to Reduce $\mathrm{CO}_{2}$ Emissions from Light-Duty Vehicles," 2009. http://eur-lex.europa.eu/LexUriServ/LexUriServ.do?uri= OJ:L:2009:140:0001:0015:EN:PDF 
[30] M. Weiss, P. Bonnel, R. Hummel, U. Manfredi, R. Colombo, G. Lanappe, P. Le Lijour and M. Scula, "Analyzing On-Road Emissions of Light-Duty Vehicles with Portable Emission Measurement Systems (PEMS)," JRC European Commission-Scientific and Technical Report, 2011.

http://www.energy.eu/publications/Analyzing-on-road-em issions-of-light-duty-vehicles-PEMS.pdf

[31] G. Santos, H. Behrendt, L. Maconi, T. Shirvani and A. Teytelboym, "Part I: Externalities and Economic Policies in Road Transport," Research in Transportation Economics, Vol. 28, No. 1, 2010, pp. 2-45. http://dx.doi.org/10.1016/j.retrec.2009.11.002

[32] Trading Economics, "Population in the Largest City (\% of Urban Population) in Denmark," 2010. http://www.tradingeconomics.com/denmark/population-i $\mathrm{n}$-the-largest-city-percent-of-urban-population-wb-data.ht $\mathrm{ml}$

[33] About France, "The Main French Towns and Cities," 2011.

http://about-france.com/tourism/main-towns-cities.htm

[34] Israel CBS - Central Bureau of Statistics, 2010.

\section{Abbreviations}

BAU, Business As Usual;

$\mathrm{CO}$, Carbon Monoxide;

$\mathrm{CO}_{2}$, Carbon Dioxide;

NMVOC, non-methane volatile organic compounds;

NOX, Nitrogen Oxides;

$\mathrm{PM}_{10}$, Inhalable Particulate Matter (smaller than $10 \mathrm{mi}-$ crometers);

$\mathrm{PM}_{2.5}$, Fine particular matter (smaller than 2.5 microme- http://www.cbs.gov.il/reader/shnaton/templ_shnaton_e.ht ml?num_tab=st02_05\&CYear $=2010$

[35] Eurostat, "Climate Change; Transport-Related Emissions," 2009.

http://epp.eurostat.ec.europa.eu/statistics_explained/index .php/Climate_change_-_driving_forces\#Transport-related emissions

[36] EPA, "Social Cost of Carbon for Regulatory Impact Analysis," 2010.

http://www.epa.gov/oms/climate/regulations/scc-tsd.pdf

[37] Renault, "Renault Unveils Finalized Designs of Fluence Z.E. and Kangoo Express Z.E,” 2010. http://www.greencarcongress.com/2010/04/renault-20100 415.html

[38] J. Kiviluoma and P. Meibom, "Methodology for Modeling Plug-In Electric Vehicles in the Power System and Cost Estimates for a System with Either Smart or Dumb Electric Vehicles," Energy, Vol. 36, No. 3, 2011, pp. 1758-1767.

http://dx.doi.org/10.1016/i.energy.2010.12.053

ters);

$\mathrm{SO}_{2}$, Sulfur dioxide;

CAFÉ, Cleaner Air for Europe;

$\mathrm{EV}$, electric vehicle;

ICE vehicle, internal combustion engine;

MoEP, Ministry of Environmental Protection;

WHO, World Health Organization;

SB, Switch Battery;

FB, Fix Battery. 